\title{
Operation of the International Monetary and Financial System - Structural Tensions of a "Non-system"*
}

\section{Gusztáv Báger}

Over the past few decades, the international monetary and financial system has been a subject of constant economic debate. More recently, topics such as the activity of global financial institutions and corporations, developments in money and capital flows, international regulation and the role of central banks were thrust into the limelight by the outbreak of the financial crisis in 2007 and its culmination into a global crisis in 2008. The depth and impact of the crisis highlighted the deficiencies of the system, prompting participants to seek solutions that may facilitate sustainable, inflation-free and balanced economic growth by eliminating or at least mitigating the negative externalities of the system.

With that in mind, one of the objectives of this study is to provide a brief presentation of the conceptual framework and main structural components of the existing system. This is also necessitated by the considerable changes that have taken place relative to the Bretton Woods system. The second objective of the study is to present a comprehensive overview of the complicated operation of the system by outlining the role and the interaction between the key elements of the system without intending to offer an in-depth examination of the details.

We found that, owing to its significant deficiencies, the international monetary and financial system fails to meet the criteria of a well-functioning system. It is not suitable to keep exchange rate and capital flow developments in balance on a global scale, to ensure an optimal level of international liquidity, and to harmonise the relationship between international (economic and monetary policy) cooperation, spillovers and diverging volatility levels.

Journal of Economic Literature (JEL) codes: G01, G010, G21, G23, F33

Keywords: monetary and financial system, global financial institutions and corporations, IMF, central banks

\footnotetext{
* The views expressed in this paper are those of the author(s) and do not necessarily reflect the offical view of the Magyar Nemzeti Bank.

Gusztáv Báger is a member of the Magyar Nemzeti Bank's Monetary Council. E-mail: bagerg@gmail.com The Hungarian manuscript was received on 4 July 2017.

DOI: http://doi.org/10.25201/FER.16.4.151186
} 


\section{Main structural components of the international monetary and financial system}

The international monetary and financial system (IMFS) includes arrangements, mechanisms and institutions designed to organise and regulate the financial exchanges and transactions between countries in relation to goods and services. Table 1 illustrates the components that make up the system and their changes.

Following the gold standard system and the gold-exchange standard operating between the two world wars, under the direction of the IMF the Bretton Woods system, which was put into a legal framework by the IMF's Articles of Agreement, was implemented and successfully operated between 1946 and 1971.

One of the most typical features of the period since the inception of the system to date is a quest to find a way to build a sustainable global monetary system built on trust rather than bullion. In the quarter century following World War II, the US dollar component of the gold-dollar currency structure was, in effect, trust-based, fiduciary money. ${ }^{1}$ In this case, the source of confidence was the United States' obligation to exchange dollars for gold at a fixed exchange rate ${ }^{2}$ and the fact that the rest of the national currencies were pegged to the dollar.

\section{Table 1}

The international monetary and financial system, then and now

\begin{tabular}{l|l|l} 
& \multicolumn{1}{|c|}{ Bretton Woods system } & \multicolumn{1}{c}{ Current system } \\
\hline Monetary anchor & Exterior: Ultimately gold & Internal goals (e.g. price stability) \\
\hline Exchange rates & Fixed, but variable exchange rate & $\begin{array}{l}\text { Mixed type (floating exchange } \\
\text { rate in focus) }\end{array}$ \\
\hline Key currencies & Actually, US dollars & Dollar dominance (less excluded) \\
\hline Capital mobility & Limited & $\begin{array}{l}\text { Mixed type (without limitation in } \\
\text { focus) }\end{array}$ \\
\hline International pass-through* & Regulated (conventions) & Cooperative collaborations, ad hoc \\
\hline Organisation, coordination* & IMF, central banks & G8, G20, IMF, central banks \\
\hline
\end{tabular}

Note: * these system components are the author's additions.

Source: BIS, 2015

In the Bretton Woods system, (partly) linking the US dollar to gold and the exchange rate negotiation mechanism operated by the IMF played a dominant role. Under the mechanism, the parity of national currencies was established in terms of the US dollar and maintained for some time (the dollar was the only currency convertible into gold). National governments were required to negotiate with the IMF with

${ }^{1}$ The Latin term fides means confidence or trust.

${ }^{2} 1$ ounce of gold $=$ USD 35 
respect to any change in the exchange rate of their national currencies. ${ }^{3}$ When a country was running a balance of payments deficit, it had access to credit from the contributions of IMF member states and from the reserves of the IMF. As such, the mechanism was based on the principle of mutual assistance.

The progress, however, was only half a step forward, as gold still remained in the system. On a positive note, the United States implicitly agreed to maintain its stock of gold through its balance of payments deficit (around USD 1.5 billion per year). The outflow of purchasing power from the United States to foreign countries significantly contributed to the recovery of global economy in general and Western Europe in particular. Meanwhile, substantial US dollar holdings had accumulated in the reserves of Western European banks, and the banks slowly started to exchange dollars for gold. Consequently, by the end of the 1960s, the gold reserves of the United States fell to USD 10 billion from around USD 25 billion in the years following the war. In the early 1950s, experts had assumed that the United States would not allow its stock of gold to fall below this - safe - level. When the US gold stock approached this level, the United States unilaterally terminated the dollar's convertibility to gold on 15 August 1971 (for more detail, see Báger 2011).

The structure and characteristic features of the new IMFS emerging from 1971-1973 were markedly different from those of the Bretton Woods system. As opposed to the exchange of dollars for gold as an external monetary anchor, the role of the internal monetary anchor increased sharply in ensuring price stability and also in terms of a number of other important economic indicators, such as the employment level in the USA. Consequently, domestic factors and objectives became the primary drivers of monetary policies. (Note that at the time of the - original - gold standard regime, exchange rate stability was practically the only economic policy objective of governments/central banks and it remained a crucial aspect in the Bretton Woods system as well).

Another important difference was the transition to a floating (market) exchange rate regime, at least in key developed countries. With the existence of various other exchange rate systems in several other countries, the new regime is considered to be a hybrid system.

While the possibility had been raised several times in professional circles (and indeed attempts have been made to that effect), no steps were taken to restore the fixed exchange rate regime. This can be partly attributed to the rapid development of information technology, which afforded quick and comprehensive access to

\footnotetext{
${ }^{3}$ If the exchange rate change was less than 10 per cent, it sufficed to notify the Board of Governors of the IMF. Any change in excess of 10 per cent had to be approved by IMF members representing at least 75 per cent of the IMF's quota.
} 
financial markets for large-scale international capital flows that by then rejected any new restrictions. To explain the reasons, we refer to Isard (2005):

- The United States, Japan and the euro area are subject to different political and economic shocks and exhibit different stabilisation responses to these shocks.

- In terms of economic performance, the three countries (groups) are in a different position, and they cannot risk giving priority to exchange rate stability over domestic macroeconomic stability.

- Maintaining greater stability of key currency exchange rates would require such an immense and consistent effort that would not have clear beneficial effects either for the countries concerned or for the rest of the world.

It should be noted that the reasons listed above can only be interpreted in relation to the Bretton Woods system; they do not rule out the possibility that the stabilisation of exchange rates would be beneficial for smaller groups of countries, integrations or currency areas. ${ }^{4}$

In the Bretton Woods system, the US dollar was clearly the world's leading currency, and it retained its dominant role even under the new IMFS. Meanwhile, however, other currencies also gained significance (initially the euro and more recently, the Chinese renminbi). As of 1 October 2016, the latter became the fifth member of the SDR basket with a weight of 10.92 per cent.

It is yet another important difference that, as opposed to the previous system, the restriction on capital flows was lifted in most developed and emerging countries in the new IMFS. The gradual unfolding of financial globalisation over the past four decades was a key driver in this process. In the context of economic globalisation, financial globalisation may be defined as the complex integration process of the financial system of a country and the country's relationship with international financial markets and institutions. In the 1980s and 1990s, this integration process was primarily dedicated to development finance. In addition to such drivers as commercial openness, the development of domestic financial systems, the level of economic development, regional integration and the establishment of financial centres, the liberalisation of domestic financial systems also facilitated the process. Besides governments and financial systems, the International Monetary Fund and the World Bank played a pivotal role in tearing down the barriers to capital flows (for more detail, see Báger 2010).

In relation to the shift to floating exchange rates and the abandonment of controls on international capital flows we should also mention the impossible trinity

\footnotetext{
${ }^{4}$ See, for example, Mundell (1960; 1961a)
} 
("trilemma") concept, which offers an important interpretation option with regard to the change in the IMFS. According to the theory developed in the early 1960s (Fleming 1962; Mundell 1961b; 1962), it is impossible for any country to maintain a fixed exchange rate regime, an autonomous monetary policy aimed at domestic stabilisation objectives, and the strong presence of mobile foreign capital at the same time. Of the three factors, the creators of the Bretton Woods system must have recognised - and obviously gave priority to - the significance of the autonomy of national monetary policy in the 1940s already, and allowed individual countries to place a restriction on international capital flows. This solution contributed significantly to ensuring the efficient operation of the Bretton Woods system up until the mid-1970s.

In the Bretton Woods system, monetary systems and conditions exerted their mutual effect on one another in a regulated, institutional form, primarily through the transactions of international trade and balance of payments items. This feature ensured and at the same time eased international macroeconomic coordination. In the new IMFS, this objective is served by the various forms of cooperation stemming from the increased role of the internal monetary anchor on the one hand and the highly diverse international spillover effects on the other hand. According to Caruana (2015), spillover effects take hold through the following four channels:

- monetary policy stance, which may support loose or tight monetary conditions;

- the international use of currencies (USD, euro, etc.), which may influence through the monetary policy of the given country - the user country's monetary policy stance;

- the integration of financial markets, which allows global common factors to move bond and equity prices;

- the availability of external funding, which can be a complement to internal loans in times of boom and economic crisis.

Through the transactions of these channels, monetary and financial regimes can reinforce each other, but they can also amplify domestic imbalances to the point of instability.

After the abandonment of the Bretton Woods system, developed countries had a clash of opinions regarding the formulation of the institutional conditions of the new IMFS. After the Group of Ten (the ten most advanced economies) had come to the foreground, the focus shifted once again to the role of the IMF and the Group of Twenty, as a ministerial-level Advisory Board. This Board had an adequate institutional background and political support on the part of both developed and emerging economies. However, it did not have any acceptable plan about how 
to restore the stability of the international payment system; consequently, the principle of exchange rate stability - despite the proposal of France and the USA in support of it - was ultimately rejected. In addition, the IMF's controlling role of exchange rate regime proved to be far weaker than anticipated, and survived only within the framework of bilateral and multilateral supervision, as reflected in the second amendment to the IMF's Articles of Agreement in 1978.

In light of the growing instability of the exchange rate regime, in the first half of the 1980s France, the USA and a few other countries repeatedly called for "a new Bretton Woods". The Group of Five (G5, composed of France, Germany, Japan, the United Kingdom and the United States), however, stood up against the proposal, taking steps in 1985-1987 such as the Plaza Agreement signed on 22 September 1985 in New York in an effort to halt the sustained multiannual appreciation of the dollar and to stabilise the rates around a new equilibrium (Boughton 2009).

From the beginning of the 1980s, various collegial leadership arrangements such as the G5, the G7 (G5 plus Canada and Italy) and then the G20 assumed an increasingly important role in international macroeconomic coordination, representing a higherlevel alternative practice than independent national policies. Experts describe the role of the USA in these bodies as first among equals.

\section{Main features of the operation of the international monetary and financial system}

Due to space limitations, the primary focus of this study is on countries wielding global influence in general and on the activity of the USA and its role in the operation of the IMFS in particular. Narrowing down our topic allows us to provide an overview of the trends in the operation of the IMFS, the main progressive changes related to the factors constituting the system and the shortfalls of the system's operation.

\subsection{Changes in exchange rates}

Floating rates are of great significance for inflation targeting monetary policies, as the exchange rate influences changes in prices. Changes in the real exchange rate also affect the current account balance. However, it poses a problem that the volatility of floating rates is greater than that of a fixed exchange rate; therefore, the intent to mitigate this volatility is understandable.

Practical experiences show that the operation of the floating exchange rate regime falls short of "textbook" expectations in several regards.

- A large part of the world employs different exchange rate regimes (fixed exchange rate regime, currency board, etc.) with significant asymmetry between some of 
these, which may give rise to inconsistent political decisions from a national and global perspective.

- The volatility of exchange rates is a typical feature, and the magnitude of this volatility is larger than warranted by either the macroeconomic fundamentals or the exchange rates of the key currencies.

- The - occasionally manipulated - changes in exchange rates contributed to the build-up of significant and persistent imbalances (the substantial balances of the current items of international balances of payments) and to the accumulation of excessively large official foreign exchange reserves. ${ }^{5}$ Numerous studies have pointed out that the deficit on the USA's current account could only be reduced with a sharp decline in the US dollar's real exchange rate. ${ }^{6}$

- Owing to the dollar's dominant role in the IMFS (Saccomann, 2012) (for example, it accounted for 87 per cent of the turnover of forex markets in April 2013 and made up 62.9 per cent of foreign exchange reserves in 2014 Q4), the United States enjoyed a privileged position in financing its external deficit at low cost.

According to its real effective exchange rate indicator, before the global financial crisis the US dollar depreciated by 25 per cent between 2002 and 2007, while the balance of payments of the USA remained above 5 per cent of GDP. As illustrated by Figure 1, following its outstanding appreciation in the first few years of the 1980s, the depreciation of the US dollar in the period of 1985-1991 was also initially accompanied by a high balance of payments deficit; the two indicators converged to a near-balance position in 1991. This convergence, however, did not occur in the period of 2002-2007: the difference between the indicators continued to grow until 2006, whereas the balance of payments deficit stood at 5.5 per cent of GDP even in 2007.

According to an analysis by the IMF (IMF 2008), the diverging trends in the two indicators can be attributed to factors such as:

- the erosion of the USA's competitiveness in the light of the real effective exchange rate, which resulted from increased trade with "low-price" emerging and developing economies in the early 1990s (Thomas - Marquez - Fahle 2008);

\footnotetext{
${ }^{5}$ Official foreign exchange reserves represent the reserve assets held by central banks, which may comprise the five freely usable currencies acknowledged by the IMF (US dollar, euro, British pound sterling, Japanese yen and, from 2016, the Chinese renminbi). The bulk of the reserves consists of allocated reserves, the currency composition of which is released by the official foreign exchange reserve databank of the IMF (COFER).

${ }^{6}$ According to econometric estimations, a 10-20 per cent real effective depreciation of the US dollar is needed in order to reduce the current account deficit of the United States by 1 per cent of GDP (Krugman 2006; Mussa 2004). See also Edwards (2005).
} 
- favourable business cycle developments up until 2006, rapid economic growth accompanied by rising imports;

- a surge in oil prices, which raised the balance of payments deficit of oil importers; and

- a financial market situation where the balance of payments deficit of the USA could be financed from FDI inflows.

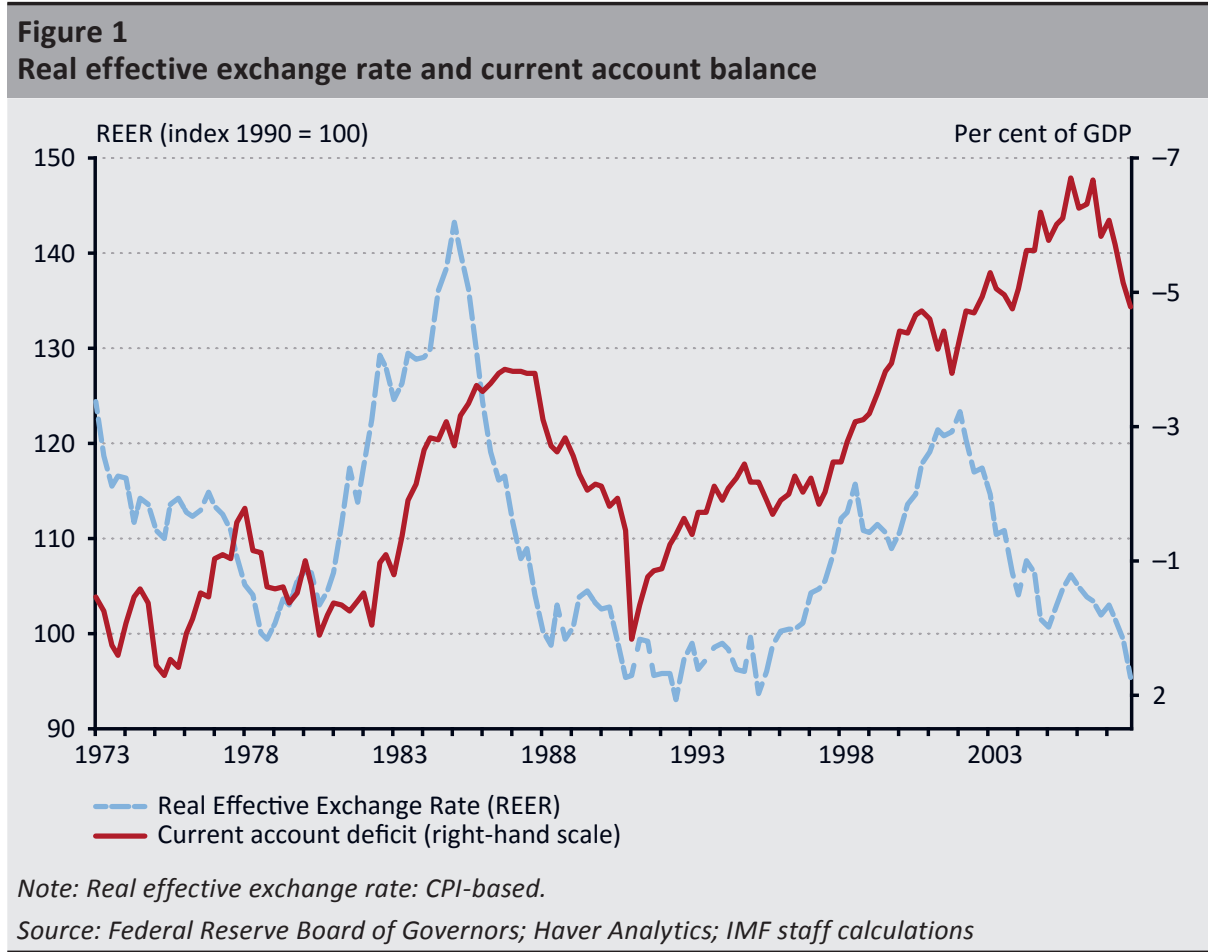

According to the assessment of the IMF's Consultative Group on Exchange Rate Issues (CGER), with the low exchange rate level reached in 2007 following the dollar's depreciation, the dollar's exchange rate became broadly consistent with its medium-term equilibrium. At the same time, however, the national currencies of numerous countries with positive balance of payments developed a close connection to the dollar, which hampered the necessary adjustment process. Indeed, rather than reducing existing imbalances or preventing the build-up of new ones, this merely resulted in the redistribution of global imbalances. 


\subsection{The emergence of global imbalances}

Another momentous phenomenon of the operation of the IMFS was the emergence of unsustainable global imbalances. The current account deficit - or surplus persisted in numerous countries and eventually posed a global challenge.

It was heightened demand for the US dollar as a reserve currency that led to the accumulation of global imbalances after the breakdown of the Bretton Woods system, especially in the years following the 1997-1998 South-East Asian crisis. Apart from China's successful growth, this was fostered by the decision of several Asian countries to accumulate dollar reserves at an increasing rate in order to prevent such crises originating from exchange rate changes as the one seen in 1997-1998. In addition, the substantial savings of Chinese households and the low savings rate of the United States also contributed to the emergence of global imbalances, the increase in China's dollar reserves and the current account deficit of the United States. ${ }^{7}$

These processes raised the deficit on the US current account balance in such a way that the increase in the deficit did not exert a significant adjustment pressure, which "normally" would have called for tight monetary policy. This, however, was not the case. We should note that even countries running balance of payments surpluses failed to experience inflationary pressures that would have prompted adjustment in similar cases. In such a situation the USA's low savings rate not only allowed but indeed, supported the accumulation of dollar reserves as did the fact that a shortage of dollars, as a reserve currency, did not cause any economic or political problems for the United States.

As a result of these underlying processes, from 1998 global imbalances started to build up on a large scale, exceeding the levels seen in previous years and peaking around 2006 (Figure 2).

In 2006, the aggregate balance of current accounts (deficits and surpluses together) equalled 5.6 per cent of world GDP; it declined by nearly one third at the height of the global crisis in 2009 and then, after a moderate increase in 2010, dropped to 3.6 per cent in 2013. Deficits accounting for larger distortions were recorded in 2006-2008 in the USA and some parts of Europe, while China, Germany, Japan and oil exporters reported considerable surpluses.

\footnotetext{
${ }^{7}$ Kürthy (2013) provides a multi-faceted, detailed analysis of the triggers of global imbalances in his study entitled "Global imbalances in a stock-flow consistent model". It is a significant accomplishment of the study that the author sought a systemic explanation to the imbalances by: analysing the conflicts arising from the co-existence of economic and social coordination mechanisms; rethinking the role of the international financial system and investigating why mainstream economics fails to give a consistent answer to the sustainability issues of global imbalances.
} 


\section{Figure 2 \\ Global current account ("flow") imbalances}

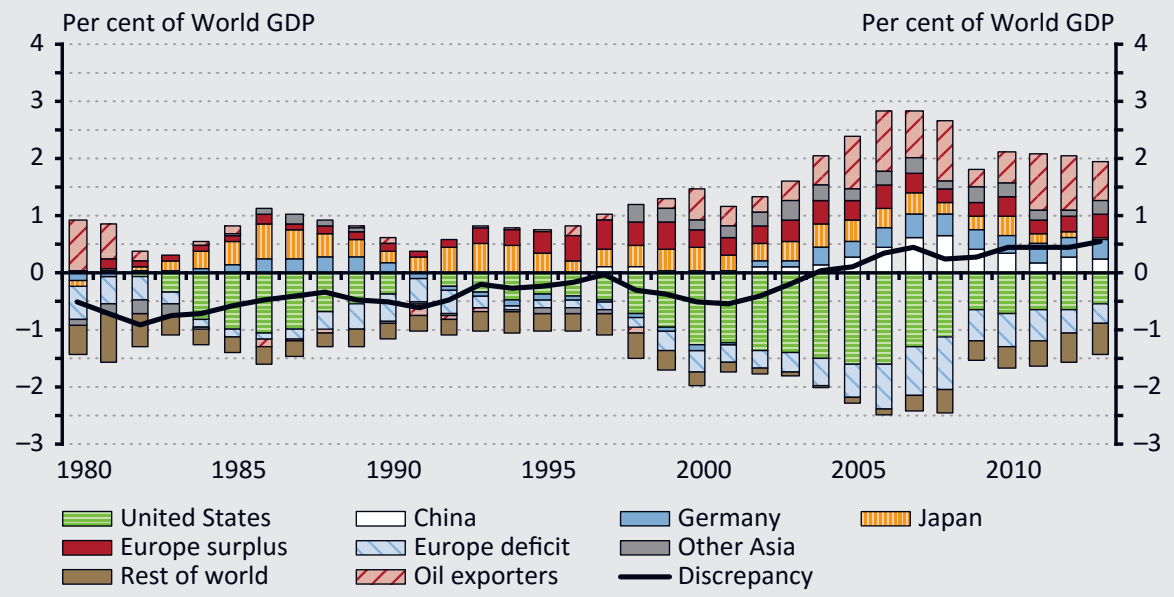

Note: Oil exporters = Algeria, Angola, Azerbaijan, Bahrain, Bolivia, Brunei, Chad, Republic of Congo, Ecuador, Equatorial Guinea, Gabon, Iran, Iraq, Kazakhstan, Kuwait, Libya, Nigeria, Norway, Oman, Qatar, Russia, Saudi Arabia, South Sudan, Timor-Leste, Trinidad and Tobago, Turkmenistan, United Arab Emirates, Venezuela, Yemen, Hong Kong Special Administrative Region, India, Indonesia, South Korea, Malaysia, Philippines, Singapore, Taiwan, Thailand. European economies (excluding Germany and Norway) are sorted into surplus or deficit each year by the signs (positive or negative, respectively) of their current account balances.

Source: IMF Staff calculations (IMF World Economic Outlook, October 2014)

The constellation of deficits and surpluses also changed significantly (Table 2).

Representing a substantial weight among the deficit economies, the US deficit accounted for -5.8 per cent of GDP in 2006. Of the ten largest deficit economies, the US figure was exceeded by Greece ( -11.3 per cent), Portugal ( -10.7 per cent), Spain ( -9.0 per cent) and Turkey (-6.0 per cent). In 2013, US deficit shrank to -2.4 per cent of GDP, while Turkey's deficit rose to -7.9 per cent. In the same year, the deficit of the United Kingdom rose to 4.5 per cent of GDP, and Brazil (-3.6 per cent), Indonesia ( -3.3 per cent), Canada ( -3.2 per cent) and Australia ( -3.2 per cent) joined the ranks of the ten largest deficit economies. 


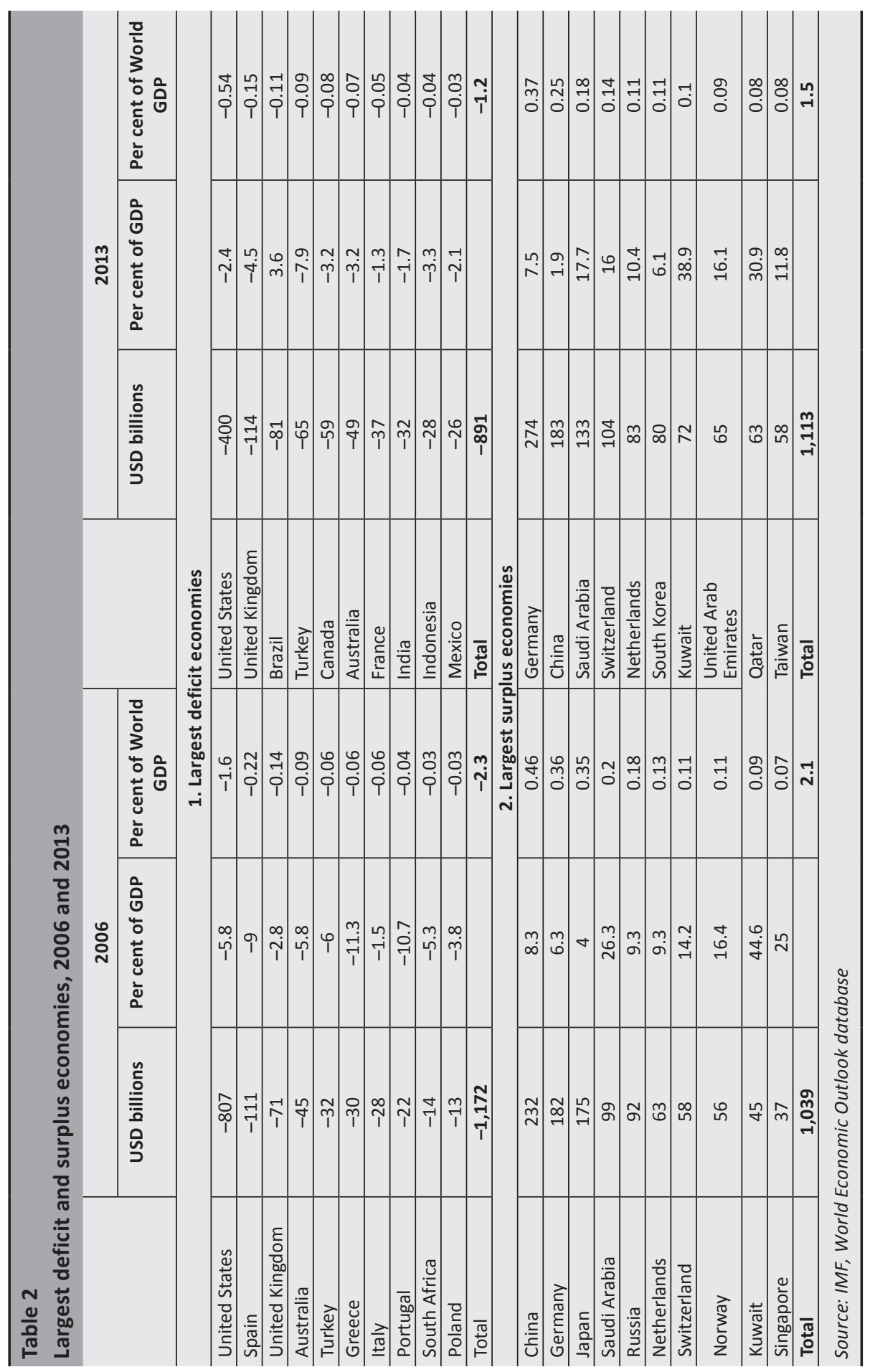


In the lead of countries running surpluses, China and Germany switched places: Germany, which took second place in 2006 with a balance of payments surplus of USD 182 billion, ran a USD 274 billion surplus in 2013, while the surplus of China amounted to USD 183 billion. In 2013, Saudi Arabia and Kuwait increased their respective surpluses of USD 99 billion and USD 45 billion in 2006 to USD 133 billion and USD 72 billion, respectively. It is noteworthy that in 2013 South Korea, Kuwait, the United Arab Emirates and Qatar joined the top 10 countries with balance of payments surpluses, while Russia dropped out.

Based on the "flow" analysis of global imbalances presented so far, we may draw the reassuring conclusion that by 2013 , the total current account balance moderated to an acceptable level as a percentage of world GDP. The USA's balance of payment deficit and the surpluses of China and Japan almost halved, although the large surpluses of some European countries and those of oil exporters persisted. In this regard, it is also a notable change that the systemic risks threatening the global economy abated significantly. However, two significant risks remained. One of them - the "price" of the moderation of external imbalances - is the exacerbation of domestic imbalances (increasing unemployment and rising output gap costs). The other risk is associated with the fact that while balance of payments ("flow") positions improved, the investment/savings positions of creditors and debtors ("stock" imbalances) diverged further.

This is why it is necessary to also analyse the evolution of imbalances on a "stock" basis, i.e. based on net external assets calculated from the balance of payments statistics. Such an analysis is especially warranted in cases when external money market conditions render economies vulnerable; for example, when external sources of finance dry up unexpectedly or a credit crunch takes hold (Catao Milesi-Ferretti 2013).

In this analytical dimension, global imbalances continued to grow even in the period of 2006-2013, in stark contrast with the result of the "flow" analysis (Figure 3). 


\section{Figure 3}

Global net foreign assets ("stock") imbalances

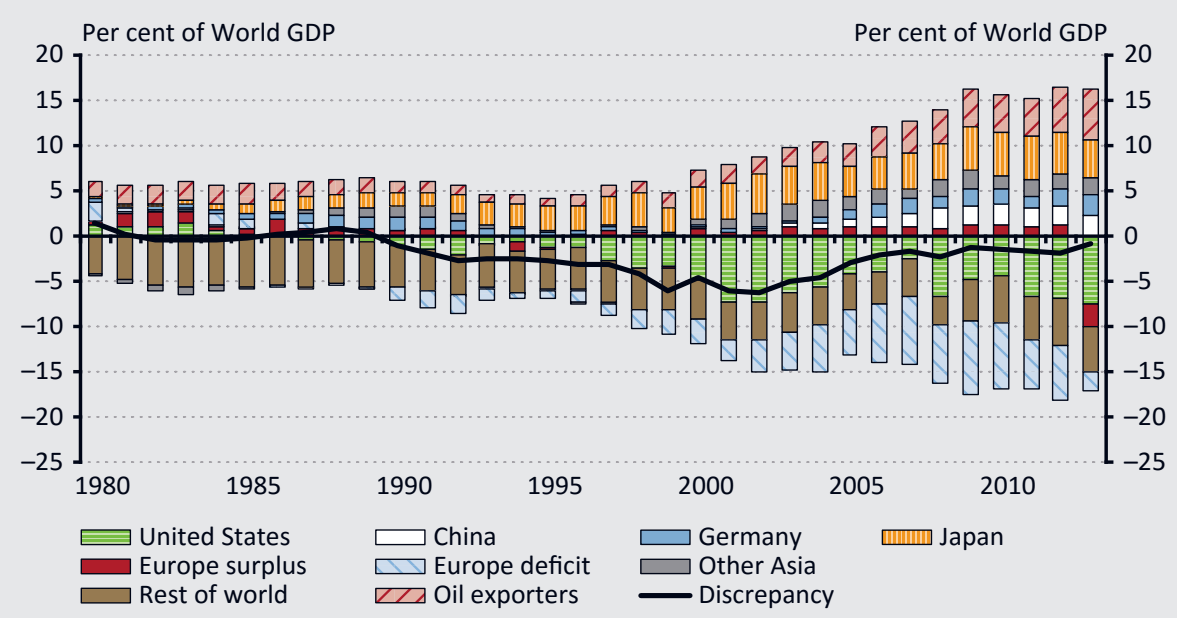

Note: Oil exporters = Algeria, Angola, Azerbaijan, Bahrain, Bolivia, Brunei, Chad, Republic of Congo, Ecuador, Equatorial Guinea, Gabon, Iran, Iraq, Kazakhstan, Kuwait, Libya, Nigeria, Norway, Oman, Qatar, Russia, Saudi Arabia, South Sudan, Timor-Leste, Trinidad and Tobago, Turkmenistan, United Arab Emirates, Venezuela, Yemen, Hong Kong Special Administrative Region, India, Indonesia, South Korea, Malaysia, Philippines, Singapore, Taiwan, Thailand. European economies (excluding Germany and Norway) are sorted into surplus or deficit each year by the signs (positive or negative, respectively) of their current account balances.

Source: IMF staff calculations. IMF World Economic Outlook, October 2014

This can be attributed to the following three groups of factors (IMF 2014b)

- Even after the significant narrowing, global flow imbalances remained positive; therefore, stock imbalances continued to widen.

- Valuation effects can change asset positions. It should be mentioned that valuation effects are influenced by the initial international investment position of the countries (creditor or debtor) and the composition of their gross assets and liabilities. The debtor position of the USA was unique in this regard: after having experienced a downward revision of its growth prospects, the value of US assets continued to rise even as its international investment positions weakened.

- Growth effects also supported higher imbalances as a share of GDP: for creditor economies, GDP growing ahead of net foreign assets lowered net foreign asset ratios, whereas in debtor economies these effects contributed to lower net foreign liability ratios. 
The level of foreign exchange reserves - another important indicator of global imbalances signalled by the position of current account balances - increased and its distribution was disproportionate (Table 3).

$\begin{aligned} & \text { Table } 3 \\
& \text { Global distribution of international reserves } \\
& \text { (USD trillions) }\end{aligned}$
\begin{tabular}{l|c|c|c|c} 
& 1998 & $\mathbf{2 0 1 0}$ & $\mathbf{2 0 1 3}$ & $\begin{array}{c}\text { Change between } \\
\mathbf{1 9 9 8} \text { and 2013 }\end{array}$ \\
\hline World & 1.6 & 9.3 & 12.1 & 10.5 \\
\hline Developed economies & 1.0 & 3.1 & 3.4 & 2.4 \\
\hline $\begin{array}{l}\text { Emerging and developing } \\
\text { countries }\end{array}$ & 0.6 & 6.2 & 8.7 & 8.1 \\
\hline
\end{tabular}

Source: IMF (2014a)

As indicated by the table, the foreign exchange reserves of the world surged to USD 12.1 trillion in one and a half decades (representing a USD 10.5 trillion increase), accounting for 16.2 per cent of world GDP in 2013. In particular, compared to the USD 2.4 trillion growth of developed countries, the growth recorded in emerging and developing countries approached USD 8.1 trillion. On the one hand, these substantial reserves boosted the countries' resilience to potential financial shocks; on the other hand, they allowed some emerging and developing countries (such as China and Saudi Arabia) to record - in addition to the exports of goods and services - significant capital outflows to advanced economies, primarily the United States. The magnitude of the US dollar reserves also poses a risk to the USA by allowing Asian creditor countries to become important actors, which may increase volatility.

Consequently, with regard to global imbalances we can conclude that in the review period, this operational deficiency of the IMFS played a prominent role in economic growth falling short of its potential in several countries, as the countries concerned were unable to reduce their balance of payments deficits and surpluses to a noticeable extent. The consequences of this failure are also evident in the euro area, where Mediterranean countries accumulated a sustained deficit, while surpluses were built up in Northern economies.

Another consequence of the imbalances was the emergence of a global savings glut. ${ }^{8}$ After the initial positive expectations, the surge in cash hoarding led to asset bubbles and a contraction in global investment opportunities. It should be borne in mind in this regard that balance of payments surpluses and the accumulation of foreign exchange reserves were not the only source of the global savings glut in several emerging economies in Asia: oil revenues deriving from the sharp rise in

\footnotetext{
${ }^{8}$ Global savings glut. The term was first used by former Fed Chairman Ben Bernanke (Bernanke 2005).
} 
international oil prices - and the simultaneous unfolding of the two processes represented an another important contributor.

\subsection{Liquidity}

Frequent swings in the ebb and flow of global liquidity represented another weakness in the operation of the IMFS. For example, the USA's accommodative monetary policy was an important factor in the liquidity tide in the early 2000s, which was also buoyed by low interest rates and risk spreads. In this environment, investors' appetite for risk increased; investments in the USA were deemed by the rest of the world both liquid and secure.

Before illustrating liquidity developments, we should briefly present the concept itself. Initially, the term "international liquidity" denoted the changeability of foreign exchange reserves. Later on, with financial globalisation and the interconnectedness of money markets the concept and the sources of liquidity expanded (Coene 2012).

The complex, multifaceted concept of global liquidity is defined by the Bank for International Settlements (BIS) and by the IMF through two components: official liquidity and market liquidity. Official liquidity is a funding opportunity that is unconditionally available to settle needs/claims through monetary authorities (central banks). This opportunity is made available through the activity of central banks with the assistance of such instruments as the foreign exchange reserves, lending, swap lines, IMF programmes and SDR allocations. These instruments are aimed at mobilising the available official liquidity the accumulation of which, ultimately, is one of the tasks of central banks. Market (private) liquidity is created by banks and other financial institutions through their operations. The common element of these two liquidity components is "ease of financing" (BIS 2011).

Owing to the extreme complexity of the concept, global liquidity developments can only be approximated with proxy indicators. According to the IMF (IMF 2007), the official liquidity position can be captured by the short-term real policy rates, the evolution of which is largely determined by the monetary policy stance (degree of accommodation) of globally important central banks. Another proxy measure is the Taylor rate or the Taylor rule, which determines the short-term policy rate based on the deviation of actual inflation from the inflation target, the neutral (long-term) real interest rate and the cyclical position of the economy. Figures 4 and 5 illustrate the key policy rates for the USA and for the euro area and their deviation from the Taylor rate.

Since the real interest rates calculated from the policy rates were negative, in the period between 1998 and 2005 the monetary policy stance of the USA can be described as strongly accommodative before - towards the end of the review period 


\section{Figure 4 \\ Interest rate-based measure of liquidity for the USA}

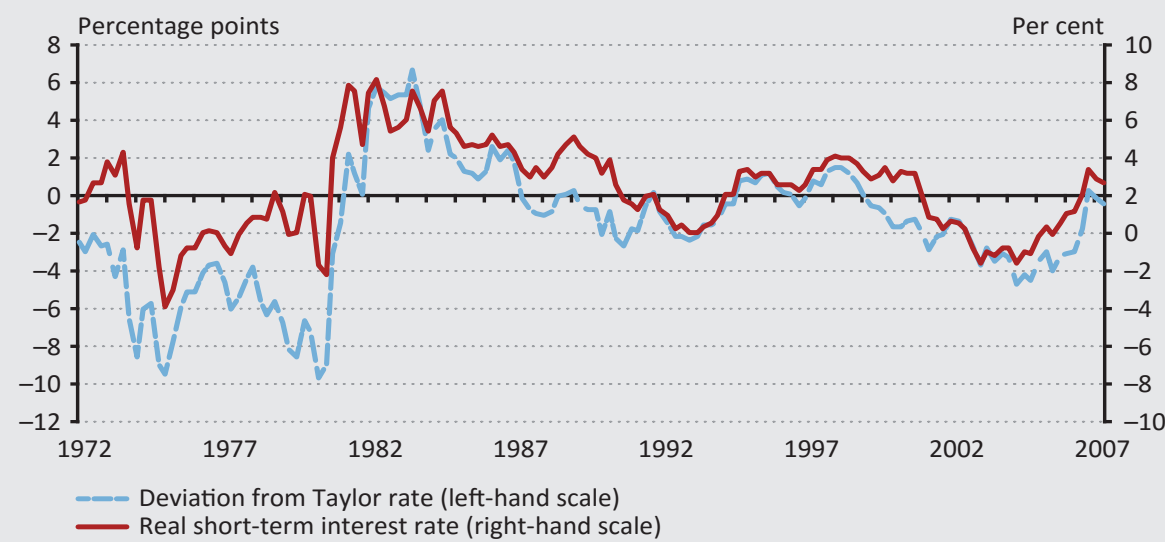

Source: IMF staff calculations. World Economic Outlook, October 2007

- the applied interest rate approached the level of the equilibrium or neutral rate of interest. In 2003-2005, monetary policy was even more accommodative than in the early 1990s. Despite the long-term similarity of the monetary adjustment path, the European Central Bank (ECB) was characterised by less pronounced monetary accommodation in the period 2003-2005 than in the 1970s, when the accommodative monetary policy stance peaked at a historical level even in the USA.

Figure 5

Interest rate-based measure of liquidity for the euro area

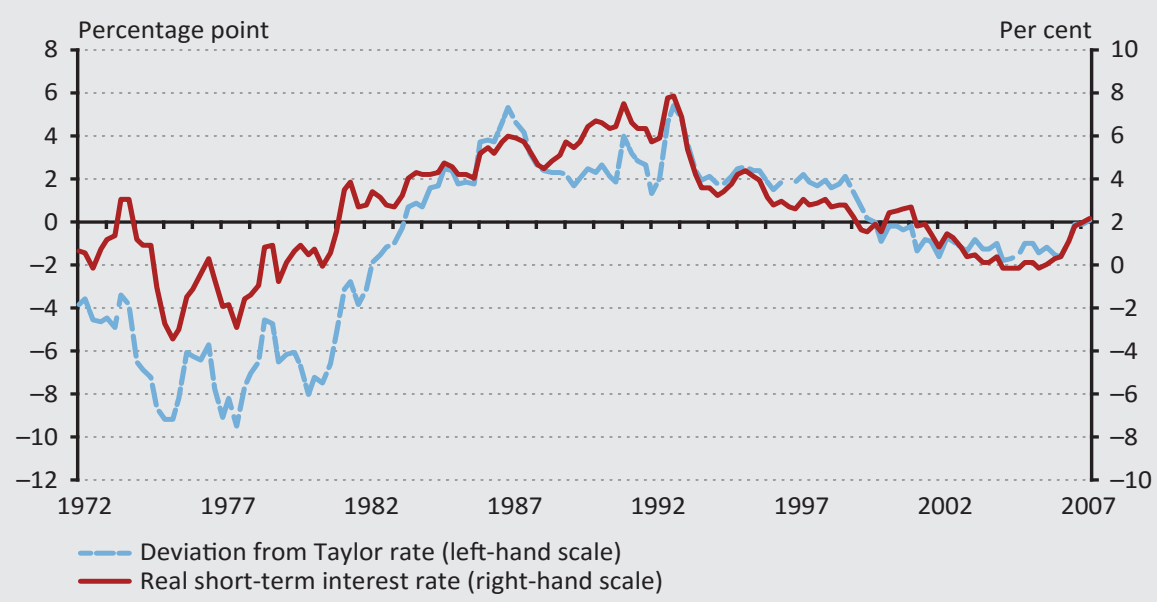

Note: Before 1998, purchasing-power-parity-weighted average of euro-area Member States. Source: IMF staff calculations. World Economic Outlook, October 2007 
According to the third, quantitative measure of global liquidity (Figure 6), monetary policy was more accommodative in the first half of the decade between 2000 and 2010 than either in the 1970s or in the middle of the 1970s, with the adjustment peaking in 2005. The increase in international foreign exchange reserves, as seen in Section 2.2, largely contributed to the liquidity expansion.

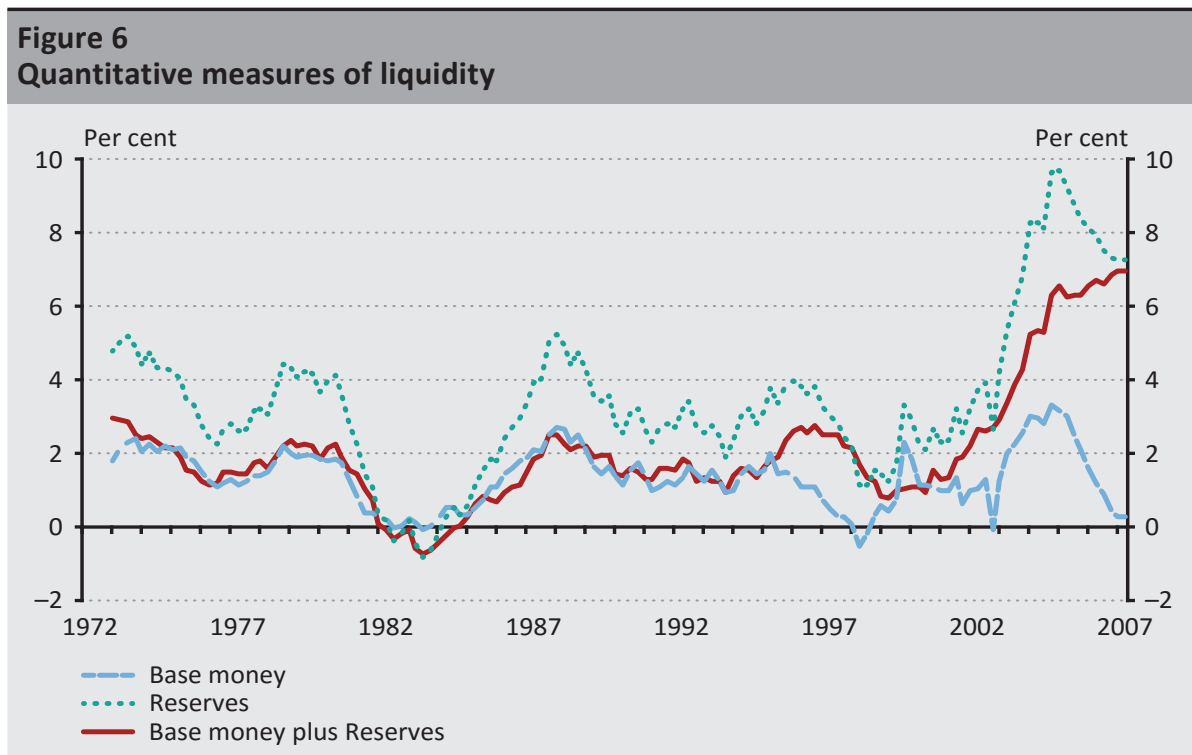

Note: Change over three years for the United States, euro area and Japan, denominated in US dollars, scaled with GDP.

Source: IMF staff calculations. World Economic Outlook, October 2007

Another group of global liquidity indicators measures the size of cross-border global (bank) loans and bond issues. One of the measures is based on a currency denomination perspective (dollar, euro, yen, etc.) (Figure 7). We compare the size of US dollar-denominated credit extended to the non-financial sector of the USA with the size of US dollar credit extended to the non-financial sector outside the USA. The figure shows that, in mid-2010, dollar credit to the non-financial sector worldwide amounted to 13 per cent of the dollar credit extended to the non-financial sector of the USA, compared to 10 per cent in mid-2000. If dollar credit to governments is excluded, the share of the international component was even higher (17 per cent) in 2010. We also find that US dollar credit to the rest of the world grew faster than credit to US residents. The latter grew around 9 per cent on average year on year between 2000 and 2007, amounting to USD 23 trillion or 167 per cent of US GDP. By contrast, the annual growth of dollar credit to the non-financial sector outside the USA was 30 per cent in the same period (BIS 2011). 


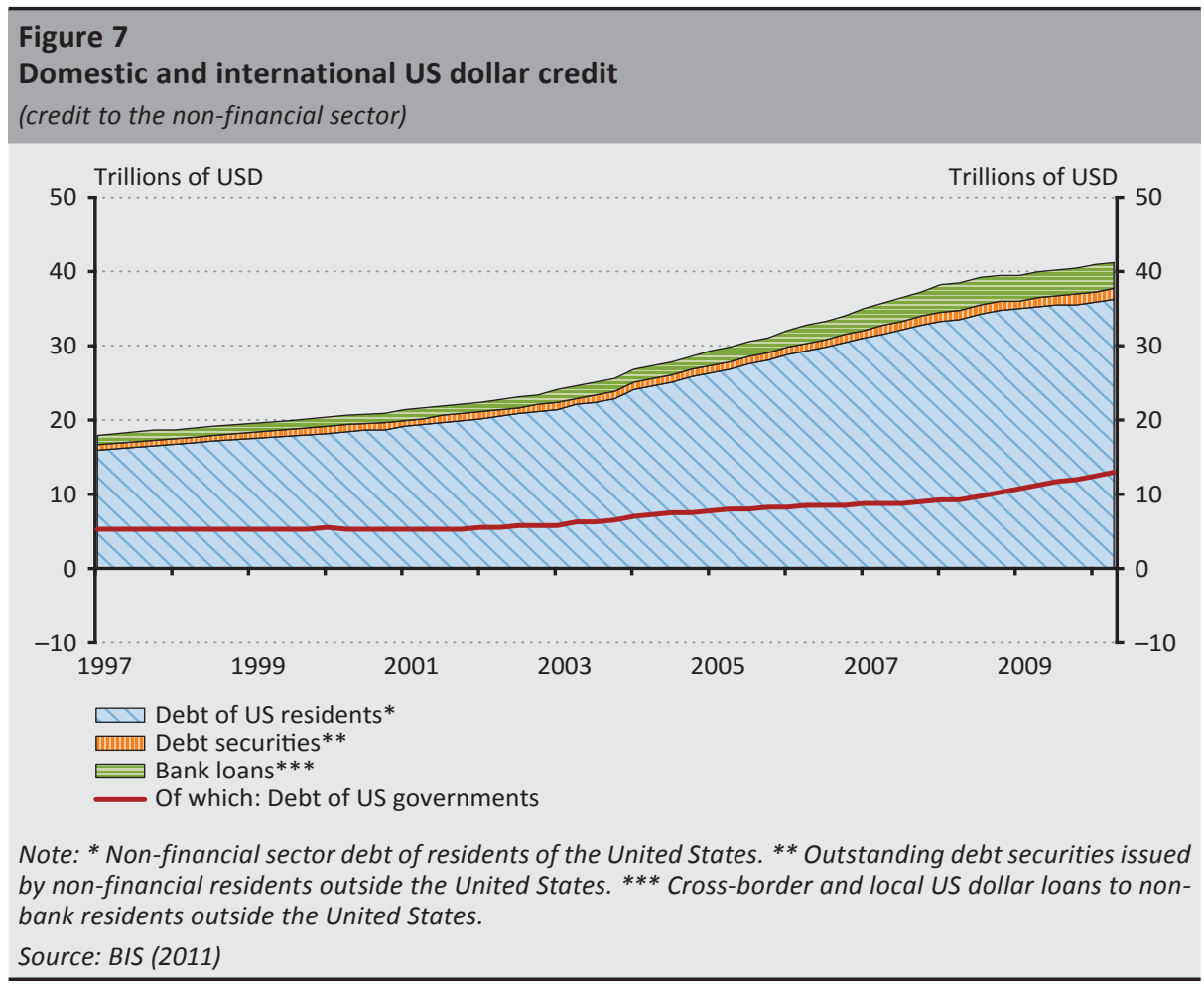

Another two approaches to measuring liquidity are credit analysis - disregarding the currency denomination - and the examination of the form of international balance sheet positions in which the credit is received by the recipient economy. With respect to the former, based on the US dollar books of a sample of European banks, before the 2008-2009 crisis many large international banks had built up in their countries sizeable US dollar asset positions through FX swaps from short-term loans, and encouraged growing exposures to investment risk (BIS 2011). As regards the latter, global credit aggregates continued to expand throughout the 2001-2010 period, while cross-border credit contracted during the years of the crisis (Figure 8). The contraction in cross-border credit was even more pronounced in the USA and more moderate in the euro area and in European emerging economies, although the downward shift had begun earlier - in 2005-2006 - in the latter regions. 


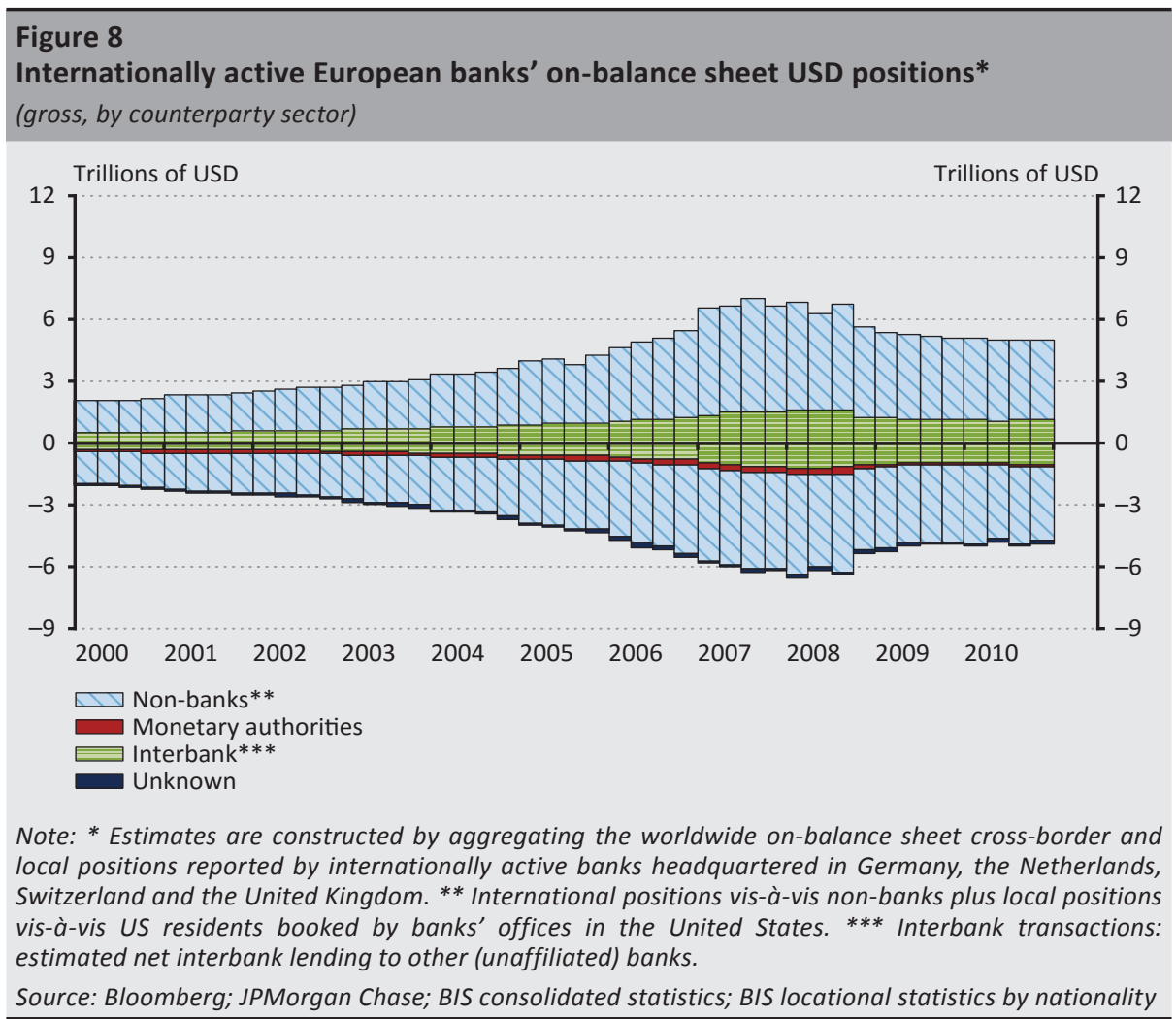

Based on the experiences of the past period, the cyclical nature of the evolution of global liquidity and the resulting shocks to financial stability indicate that liquidity exhibited substantial swings and volatility and that, owing to this reason, the sudden build-up of liquidity shortages and hence, the deceleration of economic growth, could not be prevented from time to time. The latter effect persisted particularly long during the period following the 2008-2009 crisis. Mitigating the excessive liquidity shortages became imperative in developed economies, and central banks' reciprocal FX swap arrangements served this purpose successfully (Goldberg Kennedy-Miu 2011). Besides FX swap transactions, central banks may contribute to the international distribution of liquidity with various additional instruments, such as interbank repos or cross-border collateral arrangements (CBCAs). As part of the crisis management measures, the asset purchase programmes of central banks (Fed, European Central Bank, Bank of England, Bank of Japan, etc.) have also played a pivotal role in facilitating the expansion of official liquidity in recent years. 
International financial institutions, in particular the IMF, are also important participants in mitigating liquidity shocks. The IMF has expanded the range of its lending instruments with the Flexible Credit Line (FCL) and the Precautionary Credit Line (PCL), both designed to meet the liquidity needs of countries with sound macroeconomic fundamentals for crisis-prevention measures. Another important instrument in the IMF's toolkit are Special Drawing Rights (SDR), which are primarily intended to mobilise official liquidity in respect of the key reserve currencies while they may also be used to boost global liquidity. It should be noted in this regard that, under the 14th General Review of Quotas, the overall quota was raised to SDR 477 billion (around USD 668 billion).

\subsection{Stability}

Financial stability - perhaps the most comprehensive requirement for the IMFS - has not been attained despite the fact that this deficiency jeopardises the achievement of central banks' primary objective. Efforts to strengthen stability are demanded by circumstances such as:

- the vulnerability of emerging and developing countries stemming from the fact that, on the one hand, foreign capital is present in these regions on such a large scale that the "depth" (Bernanke 2005) - level of development - of the financial sector (market) does not support its efficient operation and, on the other hand,

- that advanced economies have pursued diverging monetary policies in managing the arising macroeconomic and funding risks.

It is a complex task to define and set the objective of financial stability due to the multi-dimensional interpretation of its concept that ranges from the application of inflation targeting through asset prices, political conditions, loan sizes and changes in the financial cycle to integrated inflation targeting. The latter (new) concept is to be understood as the joint, coordinated application of monetary and macroprudential policies which, over the long run, may contribute to the sustainability of the financial system and hence, foster economic growth. ${ }^{9}$ This explains why it is so difficult to measure global stability: there is a need to define a point of reference (the equilibrium state, target levels or the prevailing trends) against which changes are compared in each dimension of stability. Moreover, the role of policies aimed directly at strengthening stability should be also determined.

In the course of crisis management, significant progress was made in this regard. It is an important achievement of the European asset quality review (AQR) that

\footnotetext{
${ }^{9}$ Macroprudential policies typically address bank lending and liquidity adequacy. As a result of the crisis and the policy pursued by the major central banks, the proportions of financing have changed: in many countries, large corporations accessed new funding primarily through bond issuance, while the share of bank financing diminished. Macroprudential policy did not - and would not be able to - follow bond issuance. Stability can only be approximated, but not fully reached, by macroprudential policy.
} 
it dissipated the uncertainties around the quality of bank assets. In addition to stress tests, the establishment of the European Single Supervisory Mechanism (SSM) succeeded in mitigating the risks surrounding banks' balance sheets and improved investors' confidence in the sector. Another important macroprudential instrument of the policies aimed at fostering stability is the countercyclical capital buffer rate, which is intended to allocate extra cushions of capital for financial crisis situations and, in the case of excessive lending, for the mitigation of financial risks. The methodological guidelines of the European Systemic Risk Board (ESRB) assist in the country-specific application of the instrument. Moreover, the efforts of the Bank for International Settlements (BIS) in formulating a credit risk measurement system also constitute an important part of the range of instruments serving stability policies.

Although short and medium-term policies tend to be in focus in terms of policies fostering stability, long-term strategic measures have an equally important role, especially with respect to the convergence of emerging and developing countries where - based on the indicators calculated from the GDP proportionate data of consolidated bank balance sheet reports - the sophistication (depth) of the financial sector lags behind the level of development in advanced economies (Table 4).

Based on the indicators, between 1989 and 2009 the depth of the financial sector increased sharply in four advanced economies (Switzerland, Belgium, United Kingdom and USA), continued to improve in Japan, and in 2009 it reached an outstanding level (21.6 per cent) in Ireland within a short period of time. Among the emerging economies, such a level of development was only observed in Hong Kong, with Singapore ranking second in this regard. The global index stood at 4.2 per cent in 1989 and by 2009 it rose to 6.7 per cent. Emerging economies contributed to this figure by 0.3 per cent in 1989 and 1.2 per cent in 2009, while advanced economies contributed by 3.9 per cent and 5.5 per cent, respectively. The indexes show that - despite the progress achieved - further stability-strengthening monetary policy measures are needed in the financial sector of emerging countries to thwart the adverse effects of external shocks. 


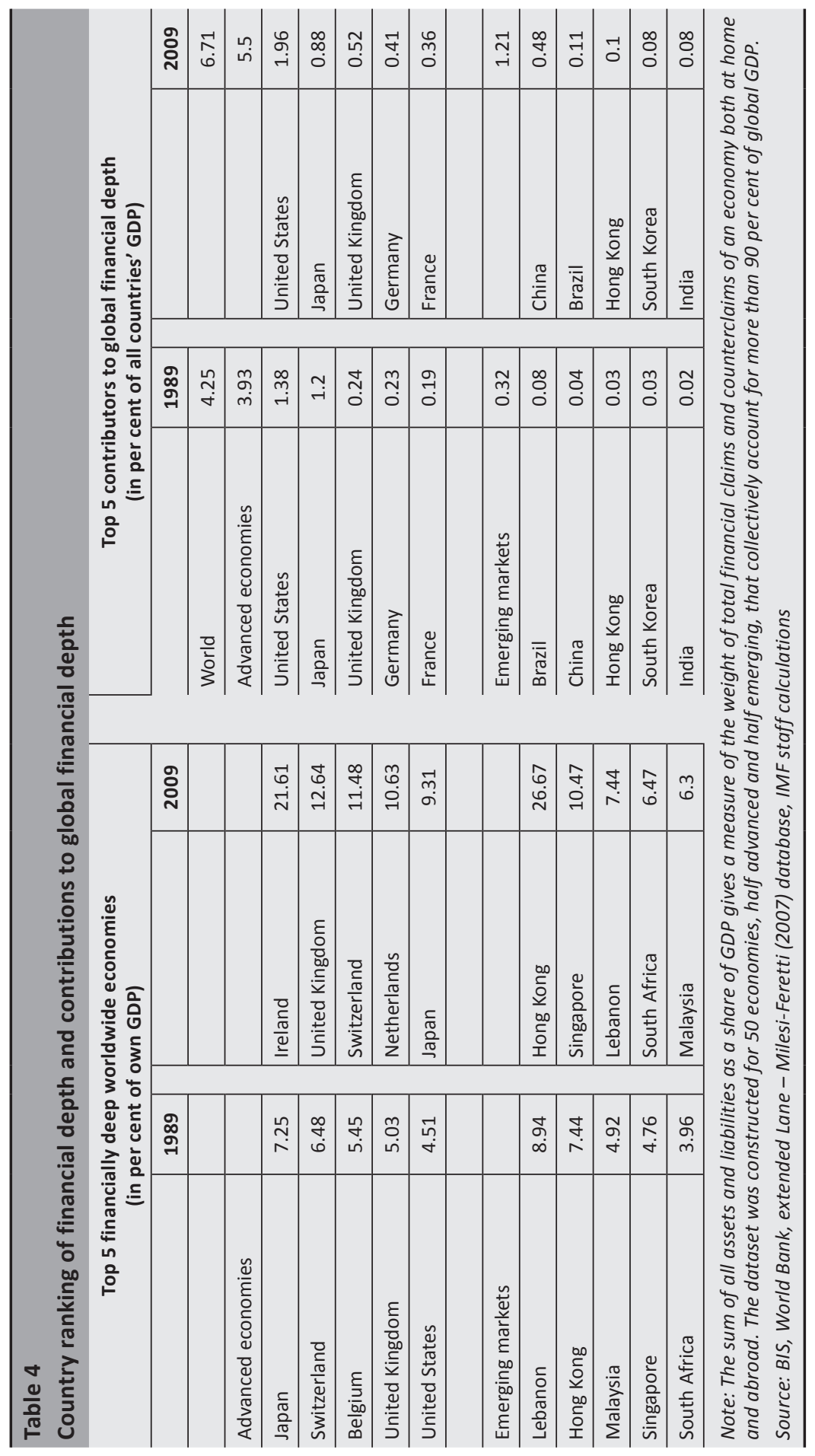


Short and medium-term analyses fostering global financial stability are based on a global financial stability map (Figure 9) (IMF 2016). According to the map, global stability improved somewhat in 2016. Macroeconomic risks remained unchanged. The continued monetary stimulus of central banks eased monetary and financial conditions, supporting a recovery in risk appetite. However, as a result of the recovery in commodity prices and external financial conditions and owing to the pickup in capital flows, market and liquidity risks remained elevated in an environment of extended realignment across major asset classes.

\section{Figure 9}

Global Financial Stability Map: Risks and Conditions

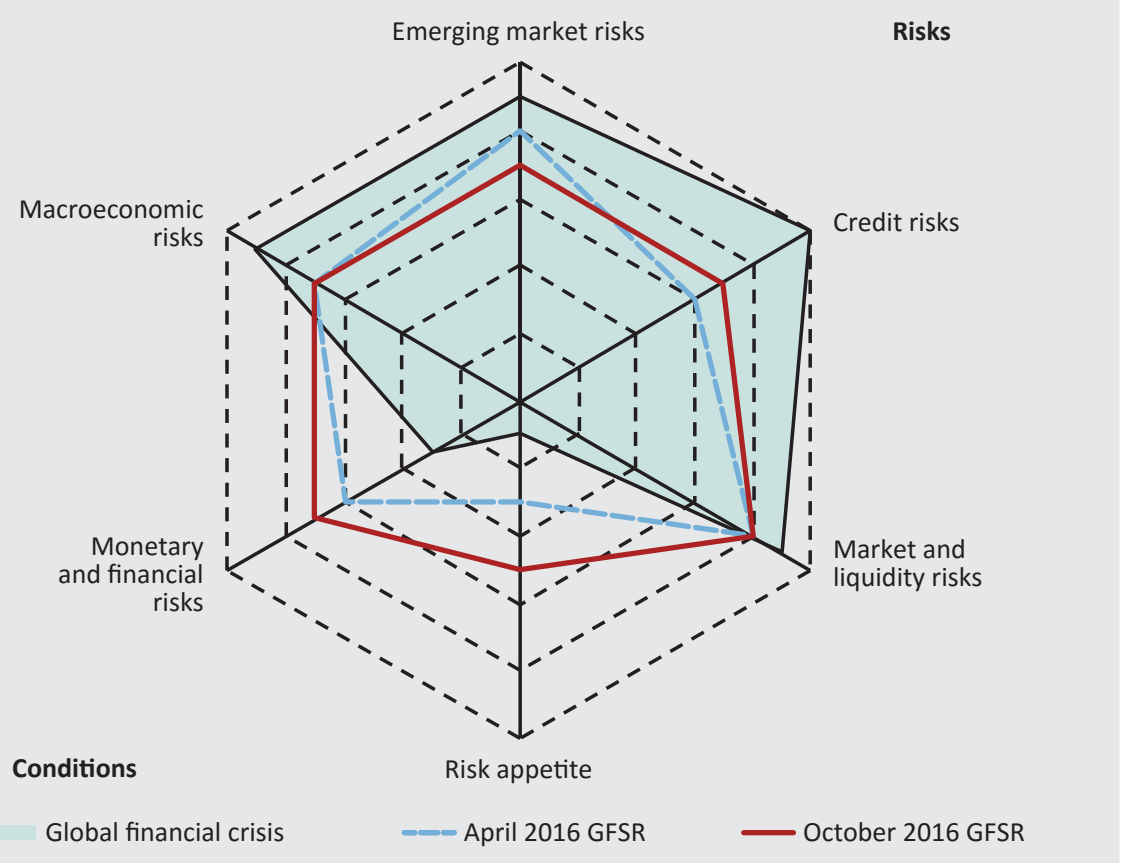

Note: Away from centre signifies higher risks, easier monetary and financial conditions, or higher risk appetite. The region shaded blue shows the global financial crisis as reflected in the stability map of the April 2009 Global Financial Stability Report (GFSR).

Source: IMF staff calculations. Global Financial Stability Report, October 2016

Despite lower short-term risks, medium-term risks were rising in 2016 as policymakers faced a wide range of vulnerabilities and new challenges. Credit risks, for example, were exacerbated by the sharp deterioration of banks' resilience in the low interest rate environment. In a broader sense, the biggest risk is posed by the USA's unbalanced politics and policy, which might lead to tighter-thanexpected financial conditions, greater fluctuations and risk aversion. Another 
challenge is posed by the worldwide trend of strengthening protectionism and hence, the deceleration in trade and economic growth. Consequently, attaining stability depends strongly on policymakers' ability to implement the right "mix" of national and global policies (IMF 2017:1).

\subsection{International spillovers}

This field merits thorough analysis not only because of the amplification of international spillover effects, but also because central banks sometimes do not appear to pay sufficient attention to harmonising these effects and the countryspecific financial conditions in making monetary policy decisions. The various facets of this challenge are aptly illustrated by the shock effects emerging in recent years in relation to the global crisis.

A prominent manifestation of these effects is the convergence of interest rates at a rate that exceeded the pace of the changes in macroeconomic fundamentals. This is evidenced by the panel regression analysis conducted by (Hofmann - Takáts 2015) for a sample composed of 30 emerging and smaller advanced economies for the period of 2000-2014. The authors found (Table 5) that a 100 basis point change in the short-term (3-month) US interbank rate induces a 34 basis point change on average in the countries under review (Column 1). Spillovers were even stronger (59 basis points) for 10 -year bond yields (Column 2). The VIX index - the other explanatory variable besides the US interest rates that is designed to capture global investment risk aversion - was another important influence on the interest rates concerned. A 100 basis point decline in the federal funds rate was associated with a 43 basis point downward shift in the policy rate of the sample countries compared to the level implied by the normative Taylor rule (Column 3). Moreover, when the examination of the effect of US policy rate was based not on the normative but descriptive Taylor-rule, then the impact was higher, 70 basis points on average, in emerging and smaller advanced economies (Column 4). Based on these findings, the USA's federal funds rate had a significant impact on the short and long-term interest rates of the 30 countries under review. 


\section{Table 5}

Interest rate spillovers ${ }^{1}$

\begin{tabular}{l|c|c|c|c}
\hline \multicolumn{1}{c|}{$\begin{array}{c}\text { Explanatory } \\
\text { variable }\end{array}$} & $\begin{array}{c}\text { Change in } \\
\text { 3-month interest } \\
\text { rates }^{2}\end{array}$ & $\begin{array}{c}\text { Change in 10-year } \\
\text { bond yields }\end{array}$ & $\begin{array}{c}\text { Dependent variable } \\
\text { Interest rate } \\
\text { deviation }\end{array}$ & $\begin{array}{c}\text { Interest rate }^{3} \\
\text { level }^{4}\end{array}$ \\
\hline US rate & $0.34^{* * *}$ & $0.59^{* * *}$ & $0.43^{* * *}$ & $0.70^{* * *}$ \\
\hline VIX & $0.51^{* * *}$ & $0.21^{* *}$ & $1.99^{* * *}$ & $1.54^{* * *}$ \\
\hline $\begin{array}{l}\text { F-stat of US output } \\
\text { and inflation }\end{array}$ & 0.24 & $2.35^{*}$ & $20.80^{* * *}$ & $6.80^{* * *}$ \\
\hline $\begin{array}{l}\text { F-stat of domestic } \\
\text { output and } \\
\text { inflation }\end{array}$ & $17.18^{* * *}$ & 2.09 & - & $12.60^{* * *}$ \\
\hline $\mathrm{R}^{2}$ & 0.25 & 0.26 & 0.45 & 0.82 \\
\hline
\end{tabular}

Note: ${ }^{1}$ Results from unbalanced fixed effects panel regressions for 30 emerging market and advanced economies (Australia, Brazil, Canada, Chile, China, Chinese Taipei, Colombia, the Czech Republic, Denmark, Hong Kong SAR, Hungary, India, Indonesia, Israel, Korea, Malaysia, Mexico, New Zealand, Norway, Peru, the Philippines, Poland, Russia, Singapore, South Africa, Sweden, Switzerland, Thailand, Turkey and the United Kingdom) for the sample period Q1 2000-Q4 2014. ${ }^{2}$ Panel estimation of $\Delta r_{t}^{i}=\beta_{0}+\alpha_{0}^{i}+\beta_{1} \Delta r_{t}^{u s}+\beta_{2} X_{t}^{i}+\varepsilon_{t}^{i}$ where $\Delta r_{t}^{i}$ indicates the quarter-on-quarter change in economy $i$ 's 3-month money market rate and 10-year bond yield and $\Delta r_{t}^{u s}$ is the change in the corresponding US rate; $X$ includes the change in US real GDP growth and inflation, the log change in the VIX and the change in domestic real GDP growth and inflation. ${ }^{3}$ Panel estimation of $i_{t}^{i}-$ Taylor $_{t}^{i}=\beta_{0}+\alpha_{0}^{i}+\beta_{1} u_{t}^{u s}+\beta_{1} X_{t}^{i}+\varepsilon_{t}^{i}$ where $i_{t}^{i}$ is the policy rate, Taylor $r_{t}^{i}$ is the policy rate implied by a normative Taylor rule (calculated following Hofmann and Bogdanova, "Taylor rules and monetary policy: a global 'Great Deviation'?", BIS Quarterly Review, September 2012, pp 37-49), $i_{t}^{u s}$ is the federal funds rate and X includes US real GDP growth, US inflation and the (log) VIX. ${ }^{4}$ Panel estimation of $i_{t}^{i}=\beta_{0}+\alpha_{0}^{i}+\beta_{1} i_{t}^{u s}+\beta_{2} X_{t}^{i}+\varepsilon_{t}^{i}$ where $X$ includes US real GDP growth, US inflation and the (log) VIX as well as domestic inflation and the domestic output gap (calculated using a standard Hodrick-Prescott filter). ${ }^{5}$ F-test of the null hypothesis that coefficients of the variables equal zero. ***/**/* denotes results significant at the $1 / 5 / 10$ per cent level based on cluster-robust standard errors.

Source: Hofmann - Takáts (2015); BIS (2015)

Another example demonstrates spillovers from the appreciation of the US dollar in emerging and developing countries. This was examined by IMF staff (IMF 2015a: 12-16) for the periods 1980-1985, 1995-2001 and 2008-2009 when emerging economies faced financial crises (Figure 10). In the period 1995-2001, US dollar appreciation took place against a background of tighter US monetary policy relative to that prevailing in Europe and Japan. During the period, emerging countries improved their net international investment positions significantly with a parallel increase in foreign exchange reserves, and - also as a result of other important development factors - emerging and developing countries in general relied increasingly on domestic resources and reduced their dependence on foreign currency debt. Emerging economies were also able to increase the share 
of domestic assets in public debt and to improve their international investment position from -40 per cent of GDP in 1995 to -25 per cent of GDP in 2013, with net debt improving by 20 percentage points of GDP and FX reserves by 10 percentage points of GDP.

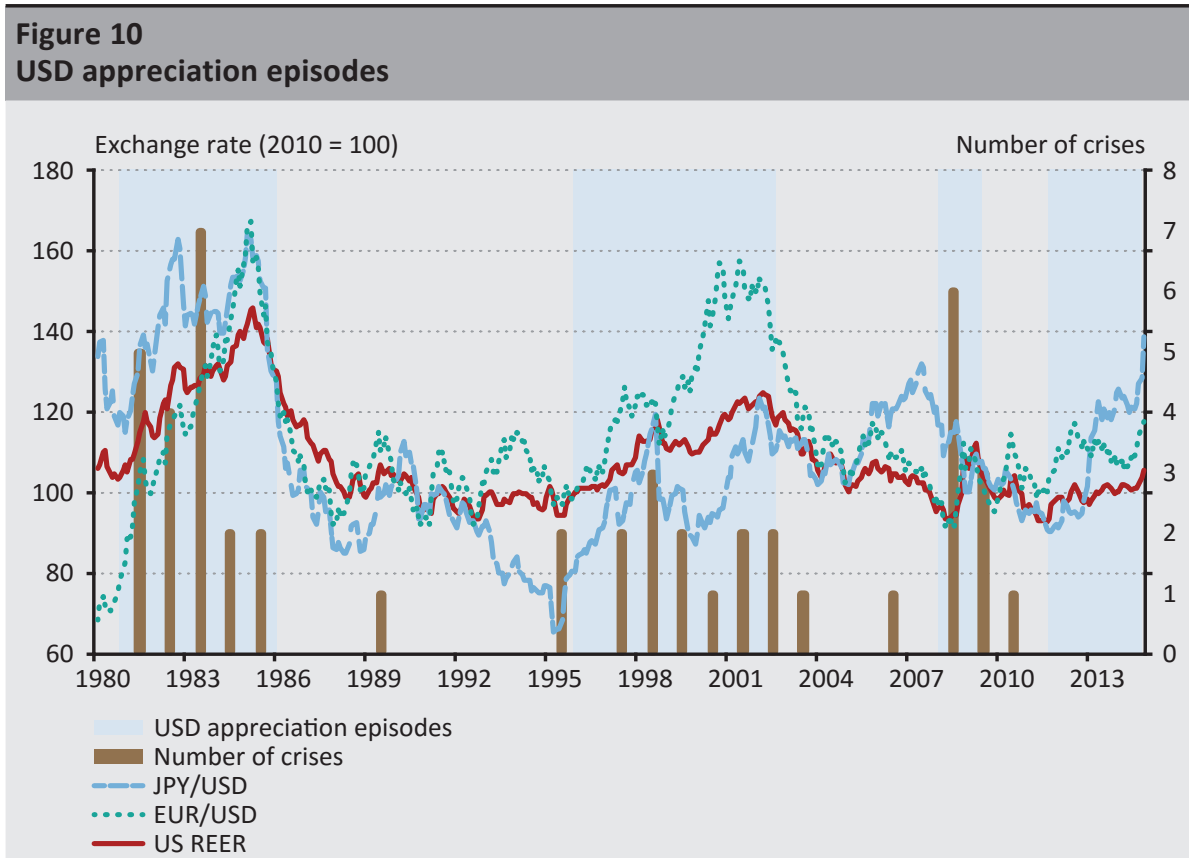

Note: Emerging market external crises include external defaults and rescheduling events, as well as the recourse to sizable multilateral financial support (IMF programmes).

Source: Chow et al. (2015)

Despite these positive effects, appreciation of the US dollar significantly increases the vulnerability of some countries. While net external positions improved, gross positions made the economy more vulnerable in countries where foreign liabilities were especially large (Chile, Hungary, Malaysia, Poland and Thailand). These liabilities underpin that, in view of the intensification of financial globalisation and, in general, international effects, a more frequent impact assessment of the implications of gross positions ("gross flows") is called for in economic policy analysis, in addition to the net external positions monitored regularly by the countries and the professional literature.

In addition, the currency composition of the FX debt position also involved vulnerabilities: naturally, the appreciation of USD affected those countries the most where dollar debt comprised the bulk of external liabilities (e.g. Turkey, China and Thailand). 
In many countries, another negative implication of USD appreciation was a sharp increase in the outstanding debt of non-financial corporations in recent decades, with a parallel rise in foreign currency debt (Figure 11).

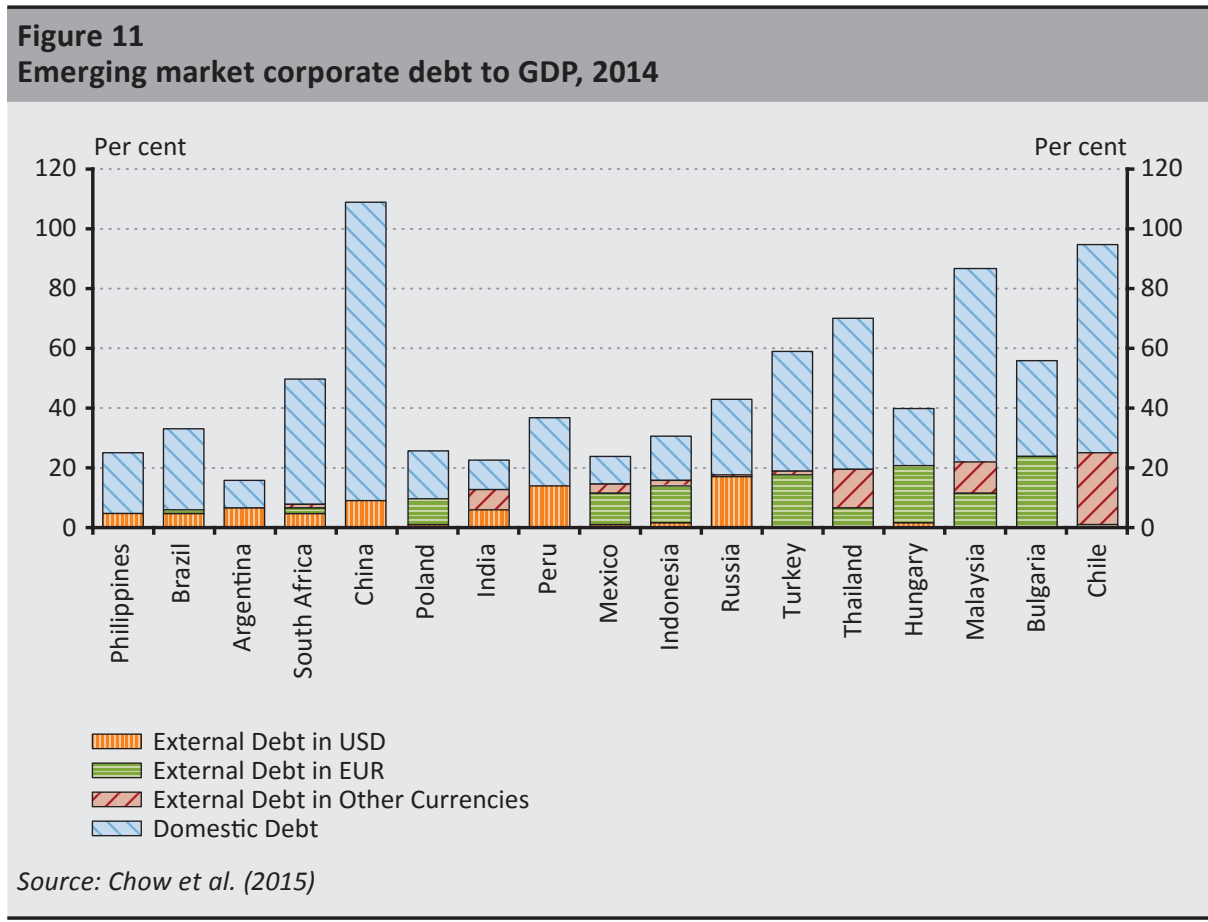

As shown in the Figure, an extremely large portion of Chinese corporate debt was denominated in the local currency. It should be borne in mind, however, that even USD-denominated Chinese debt amounted to over USD 1 trillion based on 2015 statistics. And while China's USD reserves exceed this amount, these dynamics are concerning especially in light of the fact that the country's foreign currency reserves have fallen by more than USD 1.2 trillion in recent years. Other emerging countries (primarily Chile, Malaysia, Thailand, Turkey, Russia, Bulgaria and Hungary) recorded high foreign currency debt ratios. In most of these countries, FX debt was largely denominated in US dollars, especially in Asia and Latin America but also in Turkey. In European emerging economies (Bulgaria, Hungary and Poland), the euro accounted for the lion's share of total FX debt, which made these countries less exposed to the spillover effects of USD appreciation.

As shown by these two examples, the monetary policy of the United States exerted a significant impact on the rest of the world. Similarly, the monetary policies of other globally important countries (euro area, Japan and the United Kingdom) in 
particular, may induce negative or positive effects (unfortunately mostly the former). The intensity and duration of these effects are influenced by three important factors:

- The openness of the communication cooperation and dialogue between the central banks of globally influential countries and the rest of the world. From this respect, the former group should assume a more active and initiatory role.

- The measures taken by individual countries to strengthen monetary policy transmission (e.g. in relation to non-performing loans and to the reduction or elimination of the output gap).

- The extent to which the applied policy mix - e.g. fiscal policy - supports economic growth and reduces the output gap. For example, in connection with the latter Dabla-Norris et al. (2015) pointed out that government expenditure on infrastructure development may boost economic growth and employment significantly in a low-demand environment. Of course, different policy mixes are needed in different countries and situations.

\subsection{Institutional framework}

The functioning of the IMFS is strongly affected by the operational efficiency of the institutional framework vested with international coordination. In the Bretton Woods system, the key institution in this framework was the IMF. The second amendment to its Articles of Agreement - effective from 1978 - redefined and expanded the responsibilities of the IMF in relation to the IMFS: accordingly, the IMF is expected to monitor the functioning of the system, to conduct analyses and surveys with a view to strengthening the system, and to maintain a forum of dialogue with regard to the system.

In addition to the IMF, from the mid-1970s to 1986-1987 the G5 and the G7 also played a prominent role in international coordination. Rather than making specific decisions, their role was mainly focused on formulating joint strategic opinions regarding the potential directions of economic development. This role was very successful in facilitating the spread of good practices. Some economists and policymakers (e.g. Kenen 1988; Tobin 1987) described this policy coordination as "regime preservation", which prevents international economic and financial stability from being jeopardised by certain factors. An important achievement in this endeavour was the abovementioned Plaza Accord in 1985.

The 1997-1998 regional financial crisis in South East Asia and intensifying antiglobalist social movements prompted a striking turnaround in international coordination. One sign of this was China's invitation to the $1999 \mathrm{G7} / \mathrm{G}^{10}$ Cologne summit. The event was also made memorable by the fact that summit leaders

\footnotetext{
${ }^{10}$ It was at this summit that China joined the G7, which therefore grew to become the G8.
} 
voiced concerns about developments in global debt structure for the first time, especially in view of the growing significance of derivate transactions.

Another sign of the turnaround was the presentation of the IMF's 1998 report by the managing director, which underscored, as a critical issue in the IMF's policy, the need to strengthen the architecture of the international monetary system (Address of the Managing Director 1998). The Managing Director's 1999 Address, in turn, outlined the concept and feasibility of a "managed" global financial system where, as envisioned by De Larosière, logic and ethics prevail (Address of the Managing Director 1999). The report pointed out that while the liberalisation of capital movements had sizable benefits, it also created significant risks and emphasised that, due to their special traits, this principle should be applied differently in transition and emerging economies.

This notwithstanding, the IMF was strongly criticised for the passivity exhibited before the South East Asian crisis: the Fund failed to issue an explicit warning about the development of a meltdown. Although in line with its 2005 mediumterm strategy, the IMF had launched - in justification of its activity, as it were an experimental, multilateral economic policy consultation to further partnership between the participants in an effort to reduce global financial (current account) imbalances, due to inadequate support from the key partners (the United States and China) the experiment had failed. Indeed, if for no other reason than its professional expertise, the IMF would have been rightfully expected to work out alternative solutions to mitigate or eliminate the global financial asymmetry.

It was also due to these circumstances that instead of the IMF, the G20 became the most important global forum for the coordination of economic policies in the past one and a half decades, and that a handful of major emerging economies also joined the ranks of the key actors of global economic governance. One of the most memorable moments of this change was when the functioning of the IMFS became a central item on the G20's agenda in 2011, and the Palais Royal initiative - worked out in an effort to strengthen the IMF's activity by a group of world-renown economists and politicians under the lead of former IMF managing director Michel Camdessus - became a subject of extreme interest and heated debate (Camdessus - Lamfalussy - Padoa-Schioppa 2011). The authors put forward a number of recommendations on how to strengthen the IMF's activity (how to remedy "the lack of teeth" of its procedures) and on how Europe could (would) contribute to the needed reform of the international financial system.

The principal objective of the international financial reform programme launched by the G20 in 2008 was to increase the resilience of the IMFS while preserving its open and integrated structure. The implementation of the regulatory reforms is 
coordinated by the Financial Stability Board (FSB) established in 2009, with special focus on the improvement of four major areas:

- building resilient financial institutions (implementation of Basel III capital and liquidity standards, better risk analysis, etc.);

- ending the rescue of global systemically important - too-big-to-fail - banks;

- making derivatives markets safer and

- transforming shadow banking into resilient market-based finance - regulating the shadow banking system.

Another important objective of the reform programme is to intermediate financial flows and to facilitate the financial reforms of emerging markets and developing economies.

The FSB reports on the progress of the international financial reform programme's implementation in annual reports (FSB 2015; 2016). Based on the reports, the institutional framework and programmes developed by the $\mathrm{G} 20$ have already provided adequate incentives for the countries to comply with the rules and requirements of the IMFS. ${ }^{11}$

\section{Summary conclusions}

Concurring with Jacques de Larosière's authoritative opinion, since the early 1970s the IMFS has been best described as a "non-system" rather than as a "system" (De Larosière 2012). Under such circumstances, the build-up of external imbalances perpetualised the accumulation of liquidity surpluses and - at least up until the outbreak of the 2008-2009 crisis - financial markets developed at a faster pace than the real economy. In this new world, everything has become so complex and diverse that the established intellectual premises of the IMF are no longer functioning in practice. Although on several occasions, the IMF attempted to launch a number of major reforms (Kruger 2012; IMF 2015b), due to the unravelling of financial markets and the lack of international support, they were never implemented.

Based on the analysis presented above on the operation of the IMFS, we can confirm that the functioning of the system is inadequate and inefficient. Below this finding is summarised through three relationship circles between the elements of the system.

\footnotetext{
${ }^{11}$ On a European level, the institution of the European Stabilisation Mechanism should also be mentioned, the establishment of which in 2012 represented an important step forward in the efforts to avert the spillover of a potential crisis within the euro area. It may serve as a "firewall", as it were, to prevent the insolvency of a country from triggering panic reactions in other markets.
} 
The first circle comprises capital flows, the volatility of exchange rates and the evolution of imbalances. Based on the development of the global current account imbalances shown in Section 2.2, we can conclude that countries running large deficits often lose the confidence of surplus countries, which may set in motion an exchange rate crisis between their currencies. An exception to this "rule" is the USA, which ran a substantial current account deficit for decades without giving rise to a similar crisis. As regards cross-border capital flows - the other important area of global disequilibrium - we need to point out that foreign currency debt may hurt borrowers significantly if their local currency is devalued and consequently, the repayment of their FX-denominated loans becomes far more expensive. This is exemplified by the 1997-1998 South East Asian exchange rate crisis. And if debtors are unable to repay their loans, the creditors will also suffer as their money will only be repaid, if at all, later on or only partially.

Despite these risks, capital flows were almost uniformly perceived as useful for the recipient country. Little mention was made about the challenges posed by the inflows to macroeconomic governance, the magnitude of the threats to financial stability or the impact on reserve accumulation or prudential measures. Also in view of the international spillover effects, policymakers failed to identify safer directions for capital flows or regulate the process within the framework of the IMFS.

Capital flows also contributed to the extreme volatility of exchange rates. Devaluation pressures - which improve the competitiveness of exports - posed a risk to indebted countries and to countries with large balance of payments deficits, because they may become the focus of policy decisions to such a degree that leads to a decline in internal demand. By contrast, the structural realignments in countries running balance of payments surpluses fuel even greater imbalances in deficit countries. And the often cited idea that the market (floating) exchange rate can resolve current account imbalances even in the short run has not been confirmed by practical experience. Hectic swings in the exchange rates, for the most part, did not even reflect the underlying economic trends and led to particularly large distortions in the economic development of small, open economies.

The second circle involves the attainment of the optimal level of international liquidity in a period of extreme volatility. From the aspect of the operation of the IMFS, too much or too little liquidity is no longer a theoretical but rather a practical, measurable (benchmark) issue. During the years preceding the global financial crisis, the Fed's federal funds rate was lower than the level implied by the Taylor rule. This deviation suggests that these years were characterised by excess liquidity. This lends justification to the opinion (Taylor 2007) that the Fed's monetary policy contributed to the overheatedness of the secondary mortgage market and hence, the outbreak of the global financial crisis. As the crisis unfolded, central banks attempted to resolve the drastic credit crunch with aggressive liquidity expansion, 
which was reflected in steep interest rate cuts, i.e. quantitative easing (purchases of sovereign and corporate securities directly by the central bank). The resulting liquidity situation, however, demanded excessive self insurance, which materialised as large and costly capital formation. This process continued in the years following the crisis despite the fact that volatility-induced tensions had eased somewhat. Strengthening the global financial safety net and extending the scope of cooperation between central banks may assist in scaling down this method of self insurance.

The third circle is (economic and monetary policy) cooperation, the relationship between spillovers and diverging volatilities. Before the 2008-2009 crisis, this relationship, for the most part, was lackadaisical: international cooperation did not or only slightly facilitated the development of positive spillover effects and the mitigation of volatilities. This led to the build-up of dangerous systemic risks in the financial sector, which was also boosted by the widespread application of various technical innovations.

In Section 2.5 we presented the correlation between the USA's federal funds rate and the policy rates of a number of significant countries, which indicated that the Fed's low interest rates played an important role in shaping the prices of products, services and assets in other countries. The spillover of this monetary effect incited banks and investors to take greater risks. This was reflected in the fact that lending and investment activities - primarily towards emerging smaller countries - grew at a faster pace than banks' capital. The sharp acceleration in international capital flows through the bond markets is especially evident in Latin American countries.

It is an important and progressive institutional change that willingness for cooperation between countries and financial institutions noticeably improved after the crisis. The Mutual Assessment Process (MAP) initiated by the G20 is a good example: under the MAP, with the participation of the IMF, participants analysed the countries' macroeconomic conditions and balance of payments positions in order to evaluate key imbalances. ${ }^{12}$ However, there was no change in respect of the fact that the Fed's strongly influential monetary policy and deliberations on the recent interest rate hikes in the USA focused mainly on serving domestic economic requirements and interests. Through international spillovers, this continues to shape the monetary policy stance of other countries.

The functioning of the IMFS demonstrates that more comprehensive analysis work, global discussions and greater international efforts are required for a broad-based and complex enhancement of the system. Although numerous experts concluded that the system enhancements performed after the crisis had made the operation

12 Note that in the Macroeconomic Imbalance Procedure applied by the European Commission external balance is analysed with more detailed indicators than those of the MAP process. 
of the IMFS safer, additional radical changes are needed to avoid the imminent outbreak of new financial crises.

With that in mind, the following four scenarios should be considered among the possible scenarios that may lay the foundations of the reform of the IMFS.

- Analysing the lessons of the 2008 global crisis in relation to the IMFS and aligning the resulting policy responses with the newly arising issues and challenges. This requirement may be satisfied by the financial regulatory reform of the G20 (ensuring financial stability, promoting traditional bank financing and innovative financial sources, preventing systemic risks in the operation of financial institutions, strengthening the macroprudential policy framework). The implementation of these goals is progressing according to plan, and may serve as a starting point for a more comprehensive and thorough reform of the IMFS in the near future.

- Reforming the IMFS with a focus on rule definition. The automatic international regulatory mechanisms missing from the existing system would simultaneously serve the resolution of global imbalances and balance of payments deficits, the mitigation of negative spillover effects and the justified restriction of global capital movements.

- Reforming the IMFS with the IMF in its changed role at the centre of global economy and finances. This is in part based on the broad-based quota and governance reform adopted in 2010 and taking effect in 2016 which, while expanding the funds of the IMF, increases the weight of the $\mathrm{G} 20$ and also responds to the needs of emerging and developing countries. Another condition is the reduction of the USA's current excessive role.

- Transforming the existing, USA-led, unipolar global economic system and the IMFS into a multipolar system. So far, there have been no attempts - or indeed initiatives - in this regard on the part of any of the main power centres (USA, China, euro area). With regard to the radical reform of the IMFS, the transformation of the existing system into a multipolar system and the presentation of the positions of the new power centres in terms of the possible directions of the reform merit special attention. The latter is especially intriguing in light of the unprecedented clash of opinions between the United States and the European Union and the aspects of the already existing, new regional agreements (bilateral SWAP arrangements, Chian Mai Initiative, etc.). 


\section{References}

Address of the Managing Director (1998) to the Board of Governors. Fifty-Third Annual Meeting. Washington, D.C. 6 October

Address of the Managing Director (1999) to the Board of Governors. Fifty-Fourth Annual Meeting. Washington, D.C.

Báger, G. (2010): Financial Globalization. United Nations Institute for Training and Research. Geneva, p. 62

Báger, G. (2011): Magyarország integrációja a nemzetközi pénzügyi intézményekbe (Hungary's integration into the international financial institutions). Akadémiai Kiadó. Budapest

Bernanke, B. (2005): The Global Saving Glut and the U.S. Current Account Deficit. Speech delivered at the Sandridge Lecture, Virginia Association of Economists, Richmond, VA., 10 March. Online: https://www.federalreserve.gov/boarddocs/speeches/2005/200503102/

BIS (2011): Global liquidity - concept, measurement and policy implications. Report submitted by an Ad-hoc Group established by the Committee on the Global Financial System. Bank for International Settlements, November

BIS (2015): 85th Annual Report. Bank for International Settlement. Basel, 28 June

Boughton, J.M. (2009): A New Bretton Woods? International Monetary Fund, Finance and Development, Volume 46, Number 1

Camdessus, M. - Lamfalussy, A. - Padoa-Schioppa, T. (2011): Palais-Royal Initiative. Reform of the international monetary system: a cooperative approach for the twenty first century. Online: http://global-currencies.org/smi/gb/telechar/news/Rapport_Camdessus-integral. pdf

Catão, L.A.V. - Milesi-Ferretti, G.M. (2013): External Liabilities and Crises. IMF Working Paper 13/113, International Monetary Fund, Washington (Journal of International Economics)

Coene, L. (2012): A New International Monetary System? In: Koeune, J.C. - Lamfalussy, A. (dir./eds.): In Search of a New World Monetary Order. P.I.E Peter Lang, Bruxelles, Bern, Berlin, Frankfurt am Main, New York, Oxford, Wien, pp. 161-166

Chow, J. - Jaumotte, F. - Park, S.G. - Zhang, S. (2015): Spillovers from Dollar Appreciation. Online: https://www.imf.org/external/pubs/ft/pdp/2015/pdp1502.pdf

Dabla-Norris, E. et al. (2015): The New Normal: A Sector-Level Perspective on Productivity Trends in Advanced Economies. IMF Staff Discussion Note, 15/03 (Washington: International Monetary Fund). Online: http://www.imf.org/external/pubs/ft/sdn/2015/ sdn1503.pdf 
Edwards, S. (2005): Is the Current Account Deficit Sustainable? And If not, How Costly Is Adjustment Likely to be? NBER Working Paper No. 11541 (Cambridge, Massachusetts: National Bureau of Economic Research)

De Larosière, J. (2012): Can the IMF Become the Centrepiece of the International Monetary and Financial System? In: Koeune, Jean-Claude and Lamfalussy, Alexandre (dir./eds.): In Search of a New World Monetary Order. P.I.E. Peter Lang, Bruxelles, Bern, Berlin, Frankfurt am Main, New York, Oxford, Wien, pp. 191-194

Fleming, J.M. (1962): Domestic Financial Politics Under Fixed and Under Floating Exchange Rate. IMF Staff Papers 12, pp. 969-980

FSB (2016): Implementation and Effects of the G20 Financial Regulatory Reforms. 31 August, 2nd Annual Report. Online: http://www.fsb.org/wp-content/uploads/Reporton-implementation-and-effects-of-reforms.pdf

FSB (2015): Implementation and effects of the G20 financial regulatory reforms. Report of the Financial Stability Board to G20 Leaders. http://www.fsb.org/wp-content/uploads/ Report-on-implementation-and-effects-of-reforms-final.pdf

Goldberg, L.S. - Kennedy, C. - Miu, J. (2011): Central Bank Dollar Swap Lines and Overseas Dollar Funding Costs. FRBNY Economic Policy Review, May, pp. 3-20

Hofmann, B. - Takáts, E. (2015): International monetary spillovers. BIS Quarterly Review, 13 September

IMF (2007): World Economic Outlook. Washington, D.C., October

IMF (2008): World Economic Outlook. Washington, D.C., April

IMF (2014a): Global Financial Stability Report. Risk Taking, Liquidity and Shadow Banking. Curbing Excess while Promoting Growth. October 2014

IMF (2014b): World Economic Outlook. IMF, October 2014

IMF (2015a): Spillover Report. IMF

IMF (2015b): The Managing Director's Global Policy Agenda. IMF

IMF (2016): Global Financial Stability Report. IMF, October

IMF (2017): Global Financial Stability Report. IMF, April

Isard, P. (2005): Globalization and the International Financial System. What's Wrong and What Can Be Done. Cambridge University Press

Kenen, P. (1988): Managing Exchange Rates. London, Routledge 
Kruger, A.O. (2012): Sustainability and Reform of the International Monetary System. In: Koeune, J.C. - Lamfalussy, A. (dir./eds.): In Search of a New World Monetary Order. P.I.E Peter Lang, Bruxelles, Bern, Berlin, Frankfurt am Main, New York, Oxford, Wien.

Krugman, P.R. (2007): Will There Be a Dollar Crisis? Economic Policy, 22(51), pp. 435-467. https://doi.org/10.1111/j.1468-0327.2007.00183.x

Kürthy, G. (2013): Globális egyensúlytalanságok stock-flow konzisztens modellben (Global imbalances in a stock-flow consistent model). In: Pénz, világpénz, adó, befektetések (Money, world currency, tax and investments), pp. 45-78

Mussa, M. (2004): Exchange Rate Adjustments Needed to Reduce Global Payments Imbalances. In: Bergsten, C.F. - Williamson, J. (ed.): Dollar Adjustment: How Far? Against What?

Mundell, R. (1960): The Monetary Dynamics of International Adjustment Under Fixed and Flexible Exchange Rates. Quarterly Journal of Economics, 74, pp. 227-257. https://doi. org/10.2307/1884252

Mundell, R. (1961a): The International Disequilibrium System. Kyklos, 14, Fasc. 2, pp. 153-172

Mundell, R. (1961b): Flexible Exchange Rates and Employment Policy. Canadian Journal of Economics and Political Science, 27, pp. 509-517. https://doi.org/10.2307/139437

Mundell, R. (1962): The Appropriate Use of Monetary and Fiscal Policy for Internal and External Stability. IMF Staff Papers, 12, pp. 70-79

Saccomanni, F. (2012): How to Deal with a Global Triffin Dilemma. In: Koeune, J.C. Lamfalussy, A. (dir./eds.): In Search of a New World Monetary Order. P.I.E Peter Lang. Bruxelles, Bern, Berlin, Frankfurt am Main, New York, Oxford, Wien

Taylor, J.B. (2007): Housing and Monetary Policy. In: Housing, Housing Finance, and Monetary Policy, Proceedings of the Federal Reserve Bank of Kansas City Symposium, Jackson Hole. WY. September, pp. 463-476. https://doi.org/10.3386/w13682

Thomas, C.P. - Marquez, J. - Fahle, S. (2008): Measuring U.S. International Relative Prices: A WARP View of the World. FRB International Finance Discussion Paper, No. 917 (Washington: Board of Governors of the Federal Reserve System)

Tobin, J. (1987): Agenda for International Coordination of Macroeconomic Policies. In: Paul A. Volcker et al. (eds.): International Monetary Cooperation: Essays in Honor of Henry C. Wallich, Essays in International Finance, No. 169. Princeton, NJ: Princeton University, International Finance Section, Department of Economics, pp. 61-69 